\title{
Uncertainty analysis in the application of multi-criteria decision making methods in Australian strategic environmental decisions
}

\author{
Razieh Mosadeghi ${ }^{\mathrm{a}}$, Jan Warnken ${ }^{\mathrm{b}}$, Rodger Tomlinson ${ }^{\mathrm{a}} \&$ Hamid \\ Mirfenderesk $^{\mathrm{c}}$ \\ ${ }^{a}$ Griffith Centre for Coastal Management, Griffith University, \\ Parklands Drive, QLD 4222, Australia \\ ${ }^{\mathrm{b}}$ Australian Rivers Institute, Griffith University, Parklands Drive, \\ QLD 4222, Australia \\ ${ }^{\mathrm{c}}$ Waterways and Flood Management, Gold Coast City Council, \\ Nerang, QLD 4211, Australia
}

Abstract

Multi-criteria decision making techniques have become increasingly widespread in strategic environmental decision making. In Australia these techniques are used to integrate both conservation and development aspects of natural resource use. MCDM can also evaluate the effects of uncertainties at each stage of the decision making process and examine the sensitivity of results to the inputs. This paper reviews the potential uncertainties in environmental management decision making procedures and explores how uncertainty analysis in the framework of MCDM can address some of these uncertainties. It then examines the application of MCDM in 16 Australian case studies to determine how uncertainty has been addressed in practice. Results demonstrate that appropriate use of MCDM can address uncertainties associated with decision makers' preferences and from using different techniques (epistemic uncertainty). Results also highlighted the need for incorporating visualizing techniques such as GIS and simulation algorithms (e.g. Monte Carlo Simulations) to examine the effects of uncertainty on the spatial pattern of the outcomes. This approach also presents promising ways to gain an understanding of the effects of some 
dimensions of stochastic uncertainty and assists in increasing the transparency of the decision-making process.

Keywords: Multi-criteria decision making, strategic environmental decisions, uncertainty, Australia

\section{Introduction}

In the 1960s, the first Multi Criteria Decision Making (MCDM) techniques emerged in the economic and finance sectors to alleviate difficulties in consistently handling large amounts of complex information during decision-making processes by reducing uncertainty in the integration of complex information (Steuer et al., 1996; Hajkowicz et al., 2000b;

Triantaphyllou, 2000; Zopounidis and Doumpos, 2002; Figueira et al., 2005; Dodgson et al., 2009; Koksalan et al., 2011). All MCDM techniques involve a multi-stage or multi-part process of defining objectives, choosing the criteria to measure the objectives, specifying alternatives, assigning weights to the criteria, applying the appropriate mathematical algorithm for ranking alternatives, and choosing the best alternative (Herath and Prato, 2006; Ananda and Herath, 2009; Mosadeghi et al., 2009). A summary of the MCDM framework is outlined in figure 1. Strategic environmental planning and management decisions usually relate to the allocation of natural resources to a range of uses that are frequently subject to a multitude of objectives and disparate views among stakeholders (RAC,1992; Hajkowicz et al., 2000b; Ananda and Herath, 2003; Kiker et al., 2005; Hajkowics 2008; Bryan et al., 2009).

This complexity triggered considerable interest in applying various promising MCDM techniques to these problems (e.g. Ananda and Herath, 2003; Qureshi and Harrison, 2003; Sheppard and Meitner; 2005; Herath and Prato, 2006; Zardari and Cordery, 2007; Hajkowics 2008; Higgins et al., 2008; Lai et al., 2008; Ananda and Herath, 2009; Chen et al., 2009). 
However, all decision making approaches involving natural systems face a number of uncertainties ranging from ambiguity in defining problems and goals to uncertainty in data and models (Refsgaard et al., 2007). The widely recognised importance of uncertainty in environmental decision-making prompted the development of a generic definition from a number of perspectives.

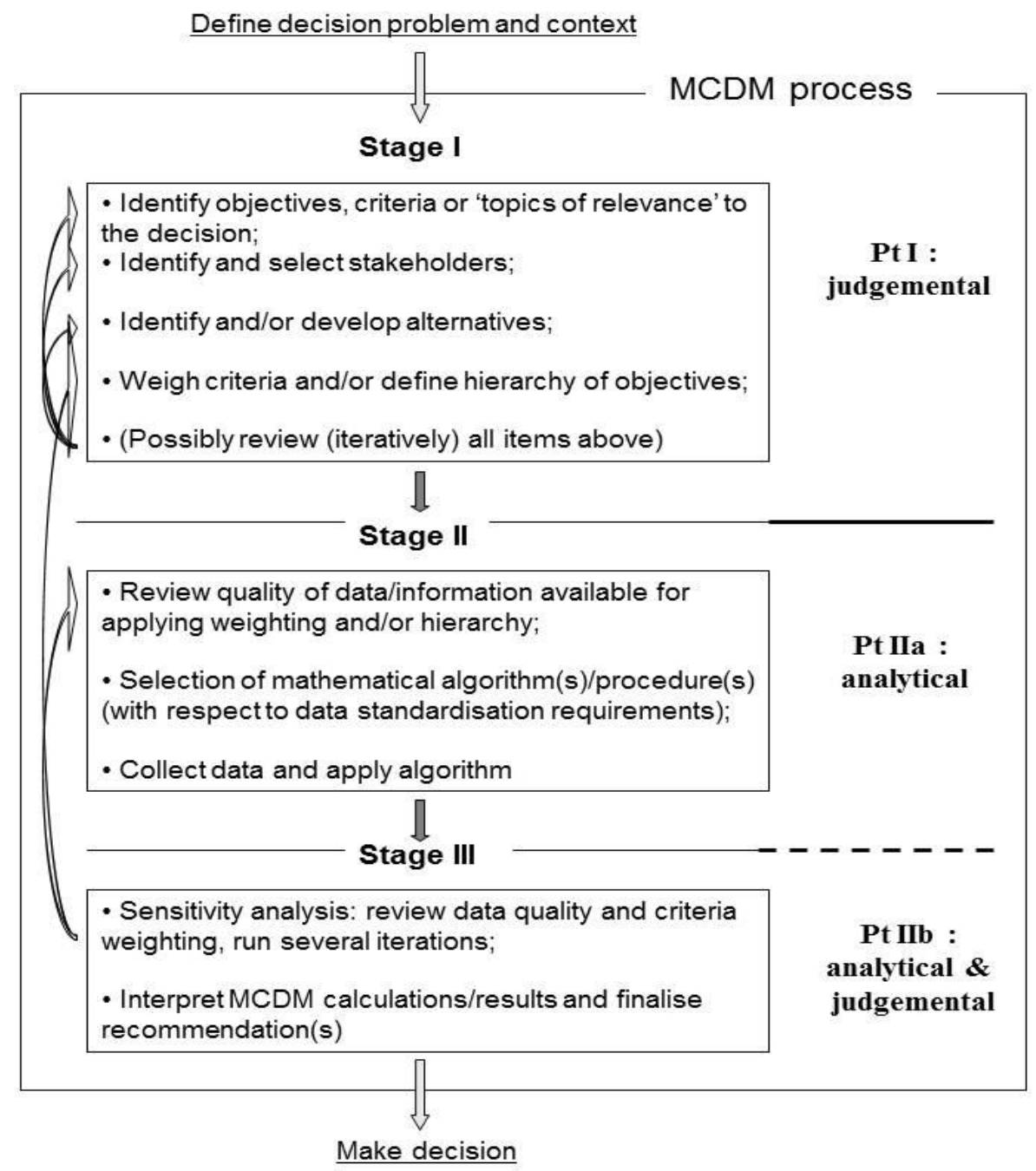

Figure 1. The overall process of multi-criteria decision making models.

Walker et al. (2003: p8) and Warmink et al. (2010: p1520), considered uncertainty as 'any departure from the unachievable ideal of complete determinism'. Other work regarded uncertainty as 'the degree of confidence a person has about the specific outcome of an event 
or action' (Klauer and Brown, 2004; Refsgaard et al., 2007). Prima facie, these definitions focus on uncertainty as a result of the imperfect knowledge of decision makers about the natural system itself (epistemic uncertainty), which may be reduced by empirical efforts (Walker et al., 2003; Refsgaard et al., 2007). Natural environments, human behavior and social dynamics remain subject to stochastic uncertainty inherent in these systems, which cannot be eliminated (Chang et al. 1993; Oreskes et al., 1994; Harremoës and Madsen, 1999; Walker et al., 2003; Refsgaard et al., 2007; Warmink et al., 2010).

During the past 10 years, the problem of uncertainties in strategic environmental decision-making has been addressed in two principally different ways. On one side, considerable resources have been allocated towards improving the accuracy of physical models that are capable of simulating and projecting hydrological, atmospheric and ecological processes (e.g. Webster, et al.,2003; Refsgaard et al., 2007; Teegavarapu, 2010) and consequently reducing model-inherent uncertainty ( Refsgaard et al., 2007). In tandem, MCDM applications continued to expand and refine their multidisciplinary approach, which now includes more sophisticated techniques allowing sensitivity and uncertainty analyses to improve knowledge integration across environmental, physical and social sciences (Hyde et al., 2005; Herath and Prato, 2006; Bryan and Crossman, 2008; Lai et al., 2008; Hajkowicz, 2009).

The growing diversity of MCDM techniques has prompted a number of reviews in recent years, which have highlighted the strengths and weaknesses of these techniques in solving environmental decision making problems (Hajkowicz et al. 2000a; Lahdelma et al. 2000; Schmoldet and Peterson, 2000; Schmoldet et al. 2001; Kiker et al. 2005; Herath and Prato, 2006; Mendoza and Martins, 2006; Ananda and Herath, 2009; Steele et al. 2009).

Although MCDM was developed as a technique to address uncertainty at different stages of decision making, its increasing sophistication in integrating and evaluating 
stakeholders' views, opinions and concerns has raised some concerns about its transparency to the end user (Ananda and Herath, 2003; Hajkowicz, 2006; Hajkowicz and Collins, 2007). Consequently non-experts, i.e. some decision-makers and stakeholders, might consider some of the sophisticated MCDM techniques as an answer-producing 'black box' (Hajkowicz and Higgins, 2008; Lai et al., 2008). In other words, the mathematical sophistication of some of the MCDM techniques to reduce potential uncertainties needs to be used carefully and weighted against any adverse clouding of transparency. On the other hand, it is important to understand that like all other environmental decision making techniques, uncertainties can manifest themselves in MCDM analyses. By providing procedures to evaluate the effects of uncertainties at each stage of the analysis, however, MCDM techniques can identify uncertainties associated with decision makers' preferences and knowledge as well as uncertainties in using different techniques. Although, there have been many empirical studies of the application of MCDM in environmental decision making, studies on how uncertainty analysis in MCDM can deal with potential uncertainties at each stage of this decision making procedure are rare.

This paper analyses MCDM to explore its capacity for addressing uncertainties likely to affect the final outcomes of strategic environmental decision making processes. The analysis is divided into three sections. The first section reviews the potential uncertainties considered relevant to environmental decision making including the location, level and nature of uncertainty. The second section highlights the different types of uncertainties that have been of concern when applying MCDM techniques to resolve environmental issues. This also includes an examination of the effect of uncertainty on spatial patterns and the need to address this issue when making a final decision or ranking the most appropriate options (Spatial Uncertainty). The third section focuses on the increasing use of MCDM techniques by Australian government agencies. This section involves a detailed examination of 16 major 
strategic environmental decisions, funded and sponsored by Australia government agencies over the last 10 years to determine how different dimensions of uncertainty were addressed.

The paper finishes with a discussion of the increasing application of MCDM and uncertainty analyses in environmental decisions and identifies gaps in current knowledge. Future research directions and ways to improve the application of MCDM in the field of environmental management are also included.

\section{Uncertainty in environmental decision making}

All environmental planning and management decisions are subject to a number of uncertainties ranging from complexities of natural systems, variable degrees of unpredictable randomness, frequent lack of sufficient data, and at times, the politicised and therefore variable interpretation of information (Refsgaard et al., 2007; Ascough et al., 2008; Zhang and Achari, 2010). The majority of these decisions tend to affect a wide range of stakeholders who often have disparate views about the relevance and weights of decision criteria (Ascough et al., 2008; Zhang and Achari, 2010). This raises the need for explicit and systematic consideration of all potential uncertainties to develop an effective solution supported by the majority of stakeholders. Accordingly, the following sections commence with a review of all uncertainty terminology and typology considered relevant in the context of environmental decision-making. This is then expanded by an analysis of the capabilities of MCDM techniques in addressing different dimensions of uncertainty and concludes by discussing spatial uncertainty as a new dimension in uncertainty analyses.

\subsection{Understanding uncertainty}

The aim of understanding and characterising uncertainty is to inform the decision makers about the likelihood of a different option being selected as a result of that uncertainty (Dorini 
et al., 2011). Despite increasing recognition of the potential effects of uncertainty, there has been little agreement on a commonly shared terminology or a generic typology of uncertainties in environmental decisions (e.g. Funtowicz and Ravetz, 1990; Morgan and Henrion, 1990;, Walker et al., 2003; Norton et al., 2006; Refsgaard et al., 2007; Ascough et al., 2008; Warmink et al., 2010; and Zhang and Achari, 2010). Nevertheless, some converging views have emerged that warrant further consideration before analysing uncertainty.

The most commonly used typology and terminology distinguishes three dimensions of uncertainty (Walker et al., 2003; Refsgaard et al., 2007; Warmink et al., 2010):

(1) the location of uncertainty - where the uncertainty manifests itself within the model structure;

(2) the level of uncertainty - where the uncertainty manifests itself along the spectrum between deterministic knowledge and total ignorance;

(3) the nature of uncertainty - whether the uncertainty is due to the imperfection of our knowledge or is due to the inherent variability of the phenomena being described.

The same three reviews continue to identify four main locations of uncertainty: Context uncertainty - includes uncertainty about the external economic, environmental, political, social, and technological situation that forms the context for the problem being examined (Walker et al., 2003; Refsgaard et al., 2007; Warmink et al., 2010). Considering this uncertainty can help to avoid problems arising from incorrect problem framing (Dunn, 2001);

Model structure uncertainty - arises from a lack of sufficient understanding of the system (past, present, or future) that is the subject of the policy analysis, including the behaviour of the system and the interrelationships amongst its elements; 
Model technical uncertainty - is the uncertainty generated by software, errors in algorithms or hardware errors (Walker et al., 2003); and

Input uncertainty - is related to data that describe the reference system, i.e. land use maps, data on infrastructure and climate data and the external driving forces that influence the system and its performance.

The same authors proceed further by distinguishing between the various levels of uncertainty as statistical, scenario, qualitative and recognized uncertainties. According to Refsgaard et al. (2007), statistical uncertainty is uncertainty which can be expressed as probabilities or alternative numerical variables. This is addressed in most traditional model uncertainty or risk assessments (Refsgaard et al., 2007; Warmink et al., 2010). Scenario uncertainty implies that there is a range of possible outcomes, but the mechanisms do not define the probability of any particular outcome. Qualitative uncertainty addresses the uncertainty that cannot be expressed in terms of nominally measurable values. In the case of recognized ignorance, uncertainty exists about the relations and mechanisms being studied, and it is therefore not possible to outline different possibilities or to give any qualification of the value of the uncertainty (Warmink et al., 2010).

The third dimension of the concept of uncertainty is known as the nature of uncertainty. Here, Walker et al. (2003) and Refsgaard et al. (2007) are in agreement by categorising the nature of uncertainty into:

- epistemic uncertainty, i.e. the uncertainty due to imperfect knowledge, which may be reduced by more precise data collection, additional monitoring and, using longer time series in modelling natural systems; and

- stochastic uncertainty as the inherent uncertainty or randomness of nature, human behaviour and social, economic, and cultural dynamics. No matter how precise the data collection is and for how long historical data time series exist, there will always 
be some uncertainty related to the chaotic nature of natural phenomena, such as global climate changes (Refsgaard et al., 2007).

These many dimensions of uncertainty informed work by Van der Sluijs et al. (2004) who proposed a catalogue of nine tools (e.g. sensitivity analysis, error propagation equations, Monte Carlo analysis, expert elicitation, etc.) for assessing and communicating uncertainty in environmental decision-making processes. This catalogue was linked to a 'Detailed Guidance' document that specified several points of consideration for decision makers who wish to elicit the relevant uncertainties in their decision process. Ultimately, the whole work was aimed at leading stakeholders to a better understanding about uncertainties, rather than devising particular solutions to address their impacts.

Refsgaard et al. (2007) further expanded on this work by reviewing a range of additional tools for uncertainty assessment, including inter alia, a data uncertainty engine, inverse modeling (parameter estimation), and uncertainty matrix. Both studies offer well-structured tables which align each assessment methodology with a particular source and type of uncertainty. Neither 'system', however, addresses the uncertainties associated with a particular approach employed to assist decision makers in identifying a solution.

The potential uncertainties in environmental decisions emphasize the need for appropriate decision-making methods to be able to address and analyze the effect of these uncertainties in the process of the making decisions for natural systems. This issue has not always received adequate attention, which may be a consequence of many experts relying primarily on the approaches with which they are most familiar and comfortable, or on methods known for their potential to generate satisfactory results under diverse conditions (Ozernoy, 1992; Poh, 1998; Sen and Yang, 1998; Li, 2007). Consequently, the next section examines the ability of MCDM techniques to address and analyze uncertainty throughout the environmental decision-making procedure. 


\subsection{Uncertainty analysis in MCDM}

MCDM techniques apply structured mechanisms and algorithms for identifying the most suitable solution for a multitude of facts, values and perceptions of stakeholders. In principle, these techniques try to overcome uncertainties in the decision-making process. Accordingly, uncertainties have been explored in the context of MCDM methodology and its wide range of applications. Detailed investigations into how the various dimensions of uncertainties in environmental decision-making could affect MCDM-assisted outcomes are rare.

Within the framework of MCDM, work on uncertainty concentrated on two main types, which, prima facie, were defined independently from the above-mentioned dimensions of uncertainty (Hyde et al., 2005; Zhang and Achari, 2010; Dorini et al. 2011; and Chen et al. 2011):

- Uncertainty in decision makers (DM) preferences and knowledge - which affects method selection, identification of evaluation criteria, and weights that DMs assign to each criterion based on their expertise.

- Model uncertainty- rises from the potential ambiguities in selected mathematical algorithms and the process of criteria estimation.

Within this framework, most of the current works have focused on addressing uncertainty in criteria weights estimation (e.g. Hyde et al., 2005; Zhang and Achari, 2010; Dorini et al., 2011; Madani and Lund 2011). The resulting methodological approaches can be subdivided into two main groups. The first concentrates on developing more sophisticated MCDM techniques, which can process uncertain or inaccurate criteria information (Lahdelma et al., 2006). Such advanced MCDM methods include ELECTRE, PROMETHEE, MAUT, Fuzzy set theory, and Random set theory (Lahdelma et al., 2006; Zhang and Achari, 2010). The Fuzzy set theory techniques are the most common techniques for dealing with imprecise 
and uncertain problems (Chen, 2005; Janssen et al., 2010; Zhang and Achari, 2010; Chen et al., 2011).

The second group of methodologies addressing uncertainty in criteria weightings consists of uncertainty analysis techniques, mostly sensitivity analysis tools. Sensitivity analyses can be performed for both stakeholder weights and attribute weights and provide DMs with an understanding of the systems behaviour under the varying nature of the preference parameters.

Generally, there are two subgroups of sensitivity analysis methods: probabilistic methods and indicator-based methods. As Chen et al. (2011) describe, probabilistic methods compute a distribution of overall scores for each alternative. The preferred alternative is then identified by comparing these score distributions, rather than the actual mean or median score. Typical analytical methods in this subgroup include Stochastic Multi-criteria Acceptability (Lahdelma and Salminen, 2001) and the commercial software Criterium Decision Plus (Murphy et al., 2001). Statistical methods such as Monte Carlo simulations and Bayesian networks are two other examples of this type of uncertainty analysis which can be undertaken in environmental MCDM applications. Monte Carlo simulation allows exploration of the full range of variation in the input factors and does not require assumption about the model structure (Madani and Lund, 2011). While in the Bayesian network three are nodes representing alternatives, attributes and external factors leading to the uncertainty of the data (Chen et al., 2011).

In addition to probabilistic methods, indicator-based sensitivity analyses methods have recently been introduced to address uncertainty. These methods use a specific indicator to describe how close the second highest scored choice is to the highest scored one (Chen et al., 2011). 
These more narrowly focused interests in solving uncertainty-related issues for MCDM applications can be attributed to the fact that most of the development of MCDM techniques still occurs outside environmental decision making processes. The result of these different approaches in analyzing the effects of uncertainty on environmental decisionmaking in general and MCDM-assisted decision-making presents itself with only very few instantaneously recognizable overlaps or linkages (e.g. linkage between stochastic uncertainty and uncertainty in decision maker's preferences. see figure 2). These differences in the approaches to catalogue uncertainties have contributed to some misunderstanding about which uncertainties can be resolved by MCDM and which cannot.

Increasingly, strategic environmental decisions have to be made not only about the preferred approach, but also where exactly this should be applied. This concern about the spatial extent of decisions warrants further consideration of uncertainties frequently associated with spatial information.

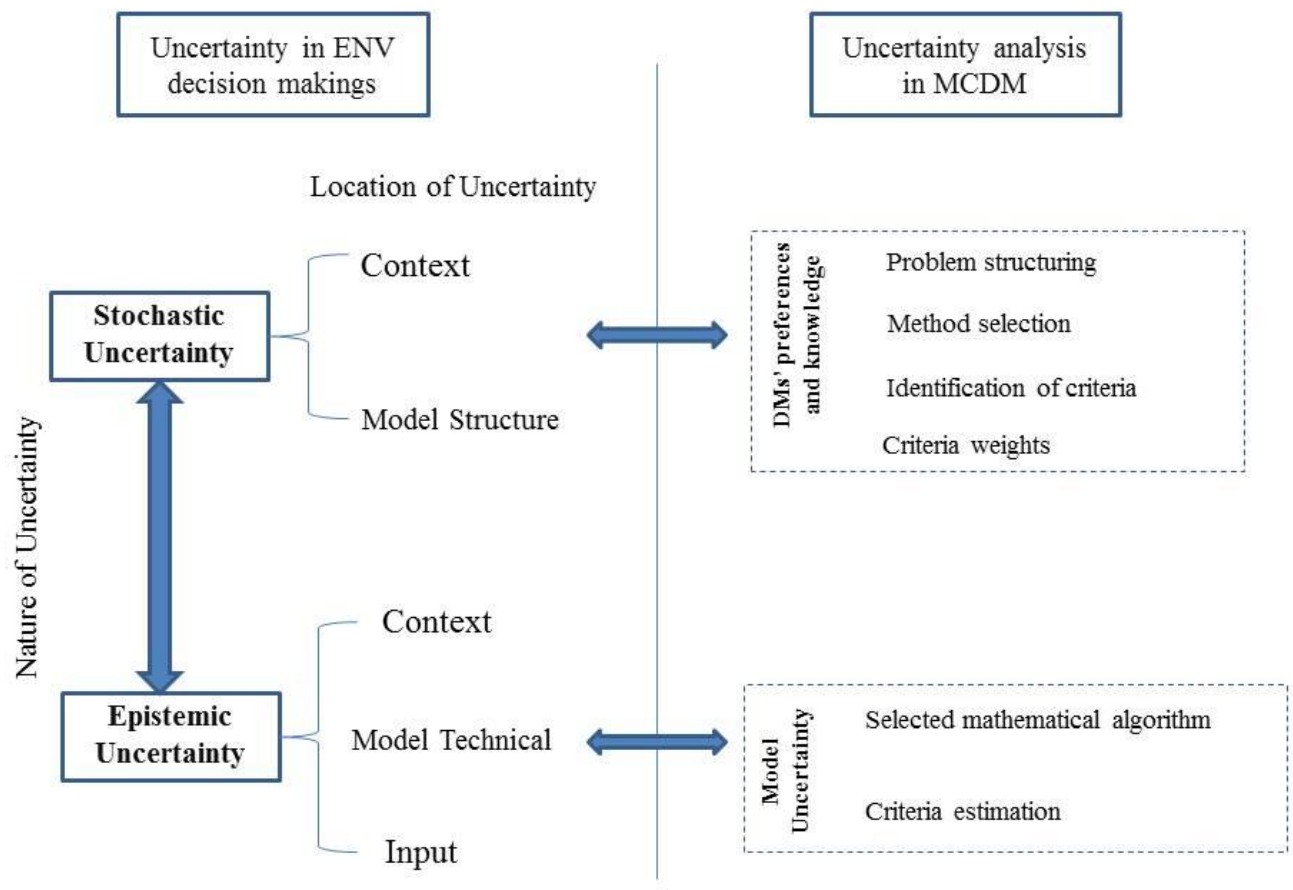

Figure 2. Linkage between uncertainty terminology in environmental decision-making science and MCDM. 


\subsection{Spatial uncertainties}

In contrast to the economic and finance sectors, the birthplace of MCDM techniques, decisions about environmental planning and management issues are indeed as much about the 'What' as about the 'Where'. In other terms: the extent of the location(s) where the highest ranking solution should be applied is often not readily defined, which adds another 'layer' of uncertainty compared to economic or financial decisions where particular points in the supply chain or existing business locations can be located without difficulty. The term 'layer' indicates that although spatial uncertainties should not be considered as a new dimension, they nevertheless appear at almost all levels so far identified in the literature (section 2.1).

Spatial uncertainty can, for example, manifest itself as input uncertainty driven by inaccurate (epistemic uncertainty) or fuzzy (unexplainable randomness - stochastic uncertainty) boundaries, point locations or extent of spatial features. Other elements include context uncertainty, i.e. the way that spatial elements influence or interact with each other; or DMs preference and knowledge uncertainty, i.e. by relying on familiar and readily available spatial information rather than considering new spatial data more suitable to addressing the problem in question.

Several analysts have already attempted to address this issue by developing MCDMmodels that tie uncertainty analyses into the visualisation capability of GIS (see Schluter and Ruger, 2007; Chen et al., 2011). These methods graphically display the output uncertainty based on the input uncertainty thereby presenting the spatial dimensions of uncertainties (Chen, et al., 2011).

\section{Environmental MCDM case studies in Australia}

In Australia, early work by the Resource Assessment Commission (RAC 1992) recognised MCDM as an approach to integrate both conservation and development aspects of alternative 
uses of natural resource (RAC, 1992). Since then government agencies including the Commonwealth Scientific and Industrial Research Organisation (CSIRO) and the Australian Bureau of Agricultural and Resource Economics and Sciences (ABARES) have been actively pursue the use of these techniques. For the purpose of this paper, application of MCDM techniques in strategic environmental decision making in Australia were examined and most recent case studies (over the past ten years) were selected for more detailed analysis. These 16 cases were selected because (i) they were funded or supported by government agencies (e.g. CSIRO), (ii) their results were publically available, and (iii) all involved concerns about uncertainty. The majority of these applications (see Table 1) related to natural resource management decisions, i.e. setting regional funding priorities (cases 1, 2, 3), identifying geographic priorities (case 8), and quantifying strategic management priorities (case 9). The remaining studies were broadly concerned about general spatial planning, forest management and water resource allocations. Each study was examined for its spatial extent; number of stakeholders or DMs; MCDM method adopted; problems confronted; types of uncertainties encountered and solutions suggested to overcome the uncertainties. Based on the nature of the given environmental decision-making problems, the 16 case studies were classified in three categories as follows.

\subsection{Natural resource management (NRM) - general aspects}

Integrated natural resource management (NRM) has been instigated in Australia through a major, national funding initiative under the National Heritage Trust (NHT) and its successive programs. Its implementation required formulation of long-term strategic decisions to identify the most effective projects based on numerous environmental, socio-cultural, and economic factors (cases 1 and 2) and also to set regional funding priorities (cases 3 and 4) and. 
The obvious potential for MCDM applications in NRM was first recognised in 2000 with a systematic analysis published by the CSIRO (Hajkowicz et al., 2000a). The report emphasised MCDM strengths as providing NRM decision-makers with a logical structure in which to solve complex problems. Major weaknesses were identified as a lack of rigour and a lack of firm foundation in economic theory (Hajkowicz et al., 2000a).

In practice and over time, the spatial scope of these MCDM applications decreased from state-wide rankings to prioritising local environmental issues. Simultaneously, their lateral scope narrowed from identifying priorities for funding any type of NHT project to focusing primarily on environmental problems as part of a regional NRM plan (Table 1). Much of this work was conducted by one author whose primary interest was to ascertain which criteria to include and to then determine which weighting methods were most amenable to stakeholders and DMs. Earlier research (Hajkowicz et al., 2000b) explored the stakeholders' perceptions of weighting methods, including fixed-point scoring; rating; ordinal ranking; a graphical method and paired comparisons. The outcomes revealed that the DMs involved in this study were more comfortable with ordinal ranking than the fixed point ranking method (case 1).

Similarly, Hajkowicz and McDonald (2006) developed the assets, threats and solvability (ATS) model for setting environmental management priorities for the Wet Tropics of north Queensland. This model was applied in conjunction with MCDM, to evaluate decision options against weighted criteria (case 3). In this study, Linear Weighted Summation was considered to be the most appropriate method because of its transparency to relevant stakeholders.

It appears that earlier choices of MCDM techniques in Australian NRM processes were largely driven by stakeholders' prior experiences and familiarity with such techniques. Taking uncertainties into consideration was not recognized as an important aspect of NRM 
issues until 2008, when Hajkowicz (2008) applied different MCDM techniques to an aggregate of 48 stakeholders from environmental, primary production and community interest groups to prioritise 30 environmental management problems in the MackayWhitsunday region of Queensland $\left(9,400 \mathrm{~km}^{2}\right)$. One of the study's key challenges was the high degree of DM preference uncertainty, i.e. strongly diverging opinions among stakeholders as to which environmental problems should receive the majority of the limited available funds. In other words, Hajkowicz (2008) recognised uncertainties incorporated in subjective judgments such as identification of evaluation criteria and decision options but did not suggest any particular methodology to specifically address this uncertainty.

More recently, Bryan et al. (2009) used MCDM to quantify strategic management priorities for natural capital and ecosystem services for the lower section of the Murray River, South Australia, which covers an area of approximately $56,000 \mathrm{~km}^{2}$. In this case, the authors employed the Analytic Hierarchy Process (AHP) (Saaty, 1980) and the Swing Weights (SW) technique (VonWinterfeldt and Edwards, 1986). The use of the two methods for different weighting purposes signifies that the authors tried to tailor their methods to the different nature (and data structure) of the problems at hand rather than relying on a more generic and transparent method. As for previous NRM studies, the research focused on identifying a common ground for management priorities across a set of decision-making groups with a diverse range of management types. Accordingly, little consideration was placed on assessing how longer-term management perspectives and their inevitable uncertainties would affect the current goal hierarchy.

A more narrowly focused aspect of NRM is regional forest planning and management. Despite involving areas smaller than general NRM projects, forestry applications of MCDM are similar. Here, these techniques can be applied to handle the complex issues arising from the multiple uses of forest goods and services, difficulties 
associated with monetary valuation of ecological services and the involvement of numerous and diverse stakeholders. Their feasibility was examined by employing Analytic Hierarchy Process (AHP) on two occasions in the north-eastern forest region in Victoria (cases 10 and 12). The strength of both studies relates to sensitivity analyses that were undertaken to minimise the criteria estimation uncertainties in the MCDM methods. Based on the results, the researchers concluded that the AHP could formalise public participation in decisionmaking and increase the transparency and the credibility of the process. These studies emphasised that the main problems associated with AHP implementation related to the (in)adequacy of the preference scale; the construction of the decision schema; the weighting, and the dependence on the structure of the decision problems (cases 10 and 12). In each case, both the DMs preference uncertainty (e.g. construction of the decision schema and structure of the decision problem) and MCDM model uncertainty (weighting uncertainty) were considered.

\subsection{Catchment management - spatial analysis and MCDM}

Unlike natural resources managers, catchment managers typically focus on smaller areas or a selected set of areas when planning and making decisions. Apart from financial planning for water service infrastructure, many issues in catchment management relate to land use intentions and restrictions. Planning documents and reference maps are commonly used to identify relevant areas. Accordingly, catchment managers have an interest in developing software applications that combine MCDM and geographic information systems (GIS). Examples from Australia include the 'Catchment Decision Assistant' (CDA) (Itami et al. 1999), Multi-Criteria Analysis Shell for Spatial Decision Support (MCAS-S) (Hill et al., 2005) and ASSESS (A System for Selecting Suitable Sites) (Bowyer and Veitch 1994). 
ASSESS implements the AHP in an operational spatial decision support system through an interface in the ArcInfo ${ }^{\circledR}$ Grid GIS environment, which has been widely used in analytical tasks of spatial decision-making processes. Although ASSESS was used to establish the current, relative, biophysical condition of Australia's surface water catchments within the intensive land use zone (Walker and Veitch, 2000; Braaten, Dowling et al., 2001), no further studies have been reported in the past 10 years.

Itami and MacLaren (2001), by applying the CDA programme, assessed the biophysical capability of land for horticultural crops in the West Gippsland Catchment in Victoria (case 6). Their work demonstrated that the limitations of the AHP in regard to ranking issues with overlapping spatial dimensions could be resolved by linking the AHP to GIS. Uncertainties however, were not considered in their research.

The MCAS-S method was introduced by the Australian Government's Bureau of Rural Sciences (2005). This method has the capacity to consider different experts' opinions and utilizes numerous spatial data. Currently, developers of the software are working on incorporating fuzzy weighting functions into the MCAS-S package, which can reduce the criteria estimation uncertainty (Lesslie et al. 2008, case 7a and 7b).

In 2008, Bryan and Crossman applied another spatial MCDM analysis tool to a $56,000 \mathrm{~km}^{2}$ area in the lower Murray River in South Australia. The tool was developed to identify geographic priorities for on-ground catchment NRM actions, such as revegetation and remnant vegetation management (case 8). Although sensitivity analysis was part of its spatial multi-criteria decision analysis (case 8), the authors neither clarified the sensitivity analysis procedure nor explained the uncertainty confronted in their work.

In contrast to broad-scale NRM problems, MCDM applications of catchment management rely predominantly on more advanced analysis techniques. It is important to note that the focus on identifying spatially referenced solutions through integration with 
inherently static GIS layers has precluded most investigators from incorporating explicit uncertainties. Despite this predicament, catchment management issues seem to have a greater general concern for criteria estimation uncertainties that has initiated the use of simple uncertainty analysis (e.g. sensitivity analysis) in this field.

\subsection{Water resource (allocation) management-large-scale decisions}

Australia, as the driest inhabited continent in the world, is faced with the challenge of finding long-term, sustainable mechanisms for water resource allocation. These should accommodate the effects of climate change and on-going development. National water reform strategies have prompted water resource managers to consider the potential advantages of MCDM applications. Common techniques in this field include PROMETHEE, the Weighted Summation Method and ELECTRE (Hyde et al. 2005; Zardari and Cordery, 2007; Hajkowikz and Higgins 2008; Kodikara 2008).

Hyde et al. (2005) re-examined the effects of changes in criteria weightings using three previously published case studies. The authors developed a new distance-based approach to overcome the shortcomings of traditional sensitivity analysis and concluded that this approach was applicable to a range of MCDM methods and would allow the most important criteria to be identified.

Xevi and Khan (2005) highlighted the need for a more detailed consideration of uncertainties associated with environmental parameters. In their study, Goal Programming (GP) was applied to solve water resource allocation problems by identifying optimal crop planting areas in response to shifting weights for a set of three management goals. The authors did not incorporate the occurrence and duration of dry and wet periods and changes to crop planting schemes (e.g. establishing citrus and stone fruit trees). Addressing these issues would have required addressing model uncertainties in their approach. 
The PROMTHEE/GAIA method was applied in combination with a water supply simulation model to rank and test 16 pre-selected operating rules for Melbourne's water supply system (Kodikara, 2008). The study used eight performance measures (PMs) under four main objectives to evaluate the system's performance in combining the interests of three key stakeholder groups (resource managers, water users and environmental interest groups). The author concluded that making these decisions 'could also have a third dimension if it involves multiple DMs and/or uncertainties in the evaluations' (Kodikara, 2008: p5). In this case, 'the uncertainties in the evaluations could mainly occur due to varying streamflow/demand patterns or different PM values suggested by different DMs' (Kodikara, 2008: p191). Kodikara (2008), case 15, focused on MCDM model uncertainties by examining the robustness of PROMTHEE as a discrete MCDM method for group decisions. The study acknowledged that the results were limited to a single stream flow and demand scenario, and that further work would be required to incorporate varying flow scenarios into this decision support framework.

Hajkowicz and Higgins (2008) applied PROMTHEE along with four other MCDM methods (Weighted Summation, range of value, Evamix and compromise programming) to a set of previously published studies concerned with ranking a range of water management decisions and projects. The five techniques produced very similar outcomes for each case. Based on these outcomes, the authors stressed again that DMs can be confused by more sophisticated and complicated techniques. On the other hand, they mention more attention should be placed on DM preference uncertainties such as problem structuring.

Model uncertainties affecting water resource allocations due to climate variability were acknowledged in most studies (cases 13 and 16). However, similar attention should be paid to DMs preference uncertainties during method selection and elicitation of criteria weights. 
To cite this article: Razieh Mosadeghi, Jan Warnken, Rodger Tomlinson \& Hamid Mirfenderesk (2012): Uncertainty analysis in the application of multi-criteria decision-making methods in Australian strategic environmental decisions, Journal of Environmental Planning and Management, DOI:10.1080/09640568.2012.717886 
1 Table1. Australian MCDM case studies

\begin{tabular}{|c|c|c|c|c|c|c|c|c|}
\hline $\begin{array}{l}\text { Case number } \\
\text { and reference }\end{array}$ & $\begin{array}{c}\begin{array}{c}\text { Location } \\
\text { and } \\
\text { spatial extent }\left(\mathrm{km}^{2}\right)\end{array}\end{array}$ & $\begin{array}{l}\text { General aim of MCDM } \\
\text { method, (decision to be } \\
\text { made) }\end{array}$ & $\begin{array}{l}\text { Pt I: definition and weighting of decision } \\
\text { criteria }\end{array}$ & $\begin{array}{l}\text { No. of } \\
\text { Participants } \\
\text { (input) }\end{array}$ & $\begin{array}{l}\text { Pt II: evaluation } \\
\text { algorithm }\end{array}$ & Confronted Problems & Uncertainty & Suggestions for further research and findings \\
\hline $\begin{array}{l}\text { 1) Hajkowicz, et } \\
\text { al., 2000b }\end{array}$ & $\begin{array}{l}\text { Five NHTi funding regions } \\
\text { in Queensland (QId) }\end{array}$ & $\begin{array}{l}\text { Ranking and selection of } \\
\text { project proposals to be } \\
\text { supported with NHT funding }\end{array}$ & $\begin{array}{l}6 \text { criteria based on } 33 \text { stakeholder interviews; } \\
\text { Comparing } 6 \text { methods: } \\
\text { - fixed point } \\
\text { - scoring } \\
\text { - rating, } \\
\text { - ordinal ranking, } \\
\text { - a graphical method } \\
\text { - paired comparisons }\end{array}$ & $\begin{array}{l}55 \text { decision } \\
\text { makers }\end{array}$ & $\begin{array}{l}\text { Not considered as } \\
\text { part of this study }\end{array}$ & None specified & $\begin{array}{l}\text { Technique } \\
\text { selection }\end{array}$ & $\begin{array}{l}\text { - Computerized and interactive MCDM models are } \\
\text { required } \\
\text { - It is undesirable to rely upon any single weighting } \\
\text { technique as there may be bias associated with that } \\
\text { particular technique } \\
\text { - Community based NRM groups prefer to work with } \\
\text { readily understandable, simple techniques }\end{array}$ \\
\hline $\begin{array}{l}\text { 2) Hajkowicz, } \\
2002\end{array}$ & $\begin{array}{l}13 \mathrm{NHT} \text { funding regions } \\
\text { covering the whole area of } \\
\mathrm{QLD}(\text { around } 1,730,500 \\
\left.\mathrm{km}^{2}\right) 1 \mathrm{~km} \text { grid data analysis }\end{array}$ & $\begin{array}{l}\text { Ranking of regional funding } \\
\text { priorities }\end{array}$ & $\begin{array}{l}9 \text { criteria with } 1 \text { to } 5 \text { descriptive parameters; } \\
\text { weighting of decision criteria to be undertaken } \\
\text { by each regional NHT body }\end{array}$ & $\begin{array}{l}\text { Variable, } \\
\text { depending on } \\
\text { each region }\end{array}$ & $\begin{array}{l}\text { Weighted } \\
\text { Summation } \\
\text { developed into an } \\
\text { Excel spreadsheet } \\
\text { model }\end{array}$ & $\begin{array}{l}\text { - Complex interplay between some } \\
\text { issues like water quality and water } \\
\text { use may not explicitly handled with } \\
\text { weighted summation technique } \\
\text {-Bias associated with data } \\
\text { availability } \\
\text { - The model may not incorporate } \\
\text { all the relevant scientific measures } \\
\end{array}$ & Input uncertainty & None specified \\
\hline $\begin{array}{l}\text { 3) Hajkowicz and } \\
\text { McDonald, } 2006\end{array}$ & $\begin{array}{l}\text { Wet tropics of north } \\
\text { Queensland } \\
20,000 \mathrm{~km}^{2}\end{array}$ & $\begin{array}{l}\text { Ranking of } 33 \mathrm{NRM} \\
\text { problems in order of priority }\end{array}$ & $\begin{array}{l}9 \text { criteria identified by NRM Board members, } \\
\text { weighted on a } 10 \text { point rating scale }\end{array}$ & $\begin{array}{l}9 \text { decision } \\
\text { makers }\end{array}$ & $\begin{array}{l}\text { Linear Weighted } \\
\text { Summation }\end{array}$ & $\begin{array}{l}\text { Priorities are highly dependent on } \\
\text { people's preferences }\end{array}$ & $\begin{array}{l}\text { Decision makers' } \\
\text { judgements }\end{array}$ & $\begin{array}{l}\text { There will be a need to balance theoretical correctness } \\
\text { against the practical needs of programme managers who } \\
\text { typically make decisions with incomplete data, limited } \\
\text { access to analytical skills and tight time frames }\end{array}$ \\
\hline $\begin{array}{l}\text { 4) Hajkowicz, } \\
2008\end{array}$ & $\begin{array}{l}\text { Mackay-Whitsunday- } \\
\text { Queensland } \\
9,400 \mathrm{~km}^{2}\end{array}$ & $\begin{array}{l}\text { Ranking of } 30 \text { environmental } \\
\text { problems in order of priority } \\
\text { for incorporation into a } \\
\text { regional NRM plan }\end{array}$ & $\begin{array}{l}9 \text { criteria taken from Hajkowicz and } \\
\text { McDonald (2006), scored for their } \\
\text { environmental performance on a } 10 \text { point rating } \\
\text { scale and then weighted by assigning } \\
\text { percentage scores }\end{array}$ & 48 stakeholders & $\begin{array}{l}\text { Linear weighted } \\
\text { summation by } 8 \\
\text { stakeholder } \\
\text { aggregated using } \\
\text { the Borda Count } \\
\text { method (d'Angelo } \\
\text { et al. 1998) }\end{array}$ & $\begin{array}{l}\text { Considerable disagreement between } \\
\text { stakeholders }\end{array}$ & $\begin{array}{l}\text { Decision makers' } \\
\text { judgement } \\
\text { incorporates } \\
\text { intuitive and } \\
\text { subjective issues } \\
\text { that are not } \\
\text { captured within } \\
\text { MCDM }\end{array}$ & $\begin{array}{l}\text { The use of MCDM do not eliminate the conflicts but } \\
\text { it helps to identify points of disagreement and facilitate } \\
\text { a structure debate about priorities enabling a final } \\
\text { decision } \\
\text { More attention needed on the selection of criteria and } \\
\text { decision options }\end{array}$ \\
\hline $\begin{array}{l}\text { 5) Bryan, et al. } \\
2009\end{array}$ & $\begin{array}{l}\text { Murray-Darling basin } \\
\text { South Australia } \\
56,000 \mathrm{~km}^{2}\end{array}$ & $\begin{array}{l}\text { Quantifying natural } \\
\text { management priorities }\end{array}$ & $\begin{array}{l}\text { Assigning weights to: } \\
\text { - capital assets (natural capital, built capital, } \\
\text { social capital) and } \\
\text { - ecosystem services (provisioning, regulating, } \\
\text { cultural, supporting) }\end{array}$ & $\begin{array}{l}13 \text { decision } \\
\text { makers }\end{array}$ & $\begin{array}{l}\text { - AHP } \\
\text { - Swing Weights } \\
\text { technique }\end{array}$ & $\begin{array}{l}\text { Using geometric means from the } \\
\text { centre of the composition of } \\
\text { weights would have provided clear } \\
\text { numerical priorities but would not } \\
\text { have been an honest representation } \\
\text { of the large variation in stakeholder } \\
\text { perspectives } \\
\text { Complexity in analysing } \\
\text { compositional data }\end{array}$ & Model uncertainty & $\begin{array}{l}\text { The regional decision-making structures could be } \\
\text { enhanced by the establishment of cross-cutting advisory } \\
\text { groups representing the different manager types }\end{array}$ \\
\hline
\end{tabular}

To cite this article: Razieh Mosadeghi, Jan Warnken, Rodger Tomlinson \& Hamid Mirfenderesk (2012): Uncertainty analysis in the application of multi-criteria decision-making methods in Australian strategic environmental decisions, Journal of Environmental Planning and Management, DOI:10.1080/09640568.2012.717886 
3 Table 1. Continued

\begin{tabular}{|c|c|c|c|c|c|c|c|c|}
\hline $\begin{array}{l}\text { Case number and } \\
\text { reference }\end{array}$ & $\begin{array}{c}\text { Location } \\
\text { and } \\
\text { spatial extent } \\
\left(\mathbf{k m}^{2}\right)\end{array}$ & $\begin{array}{l}\text { General aim of MCDM } \\
\text { method, (decision to be } \\
\text { made) }\end{array}$ & $\begin{array}{l}\text { Pt I: definition and weighting of } \\
\text { decision criteria }\end{array}$ & $\begin{array}{l}\text { No. of } \\
\text { Participants } \\
\text { (input) }\end{array}$ & Pt II: evaluation algorithm & Confronted Problems & uncertainty & Suggestions for further research and findings \\
\hline $\begin{array}{l}\text { 6) Itami and } \\
\text { MacLaren, } 2001\end{array}$ & $\begin{array}{l}\text { West Gippsland } \\
\text { Catchment, Victoria } \\
20,250 \mathrm{~km}^{2}\end{array}$ & $\begin{array}{l}\text { Creating a spatial MCDM } \\
\text { model to assist catchment } \\
\text { management }\end{array}$ & $\begin{array}{l}3 \text { database layers comprising } 350 \text { maps } \\
\text { including climate layers for Victoria }\end{array}$ & $\begin{array}{l}\text { A group of } 3 \\
\text { experts }\end{array}$ & $\begin{array}{l}\text { Spatial AHP model } \\
\text { Computer program written in } \\
\text { Visual Basic }\end{array}$ & $\begin{array}{l}\text { This package requires a map } \\
\text { database with high level of } \\
\text { integrity }\end{array}$ & Input uncertainty & $\begin{array}{l}\text { The integration of the AHP with GIS provides a } \\
\text { powerful tool for ranking sites } \\
\text { Participants find the process compelling because } \\
\text { of visual interaction on computer }\end{array}$ \\
\hline 7a) Lesslie et al. 2008 & $\begin{array}{l}\text { West Hume area of } \\
\text { southern New South } \\
\text { Wales } \\
860 \mathrm{~km}^{2}\end{array}$ & $\begin{array}{l}\text { Defining appropriate } \\
\text { locations for catchment } \\
\text { revegetation }\end{array}$ & \multirow[b]{2}{*}{$\begin{array}{l}\text { Ranking the relative importance of } 10 \\
\text { biodiversity rules and } 20 \text { salinity } \\
\text { guidelines (rules) }\end{array}$} & \multirow[b]{2}{*}{ Not mentioned } & \multirow{2}{*}{$\begin{array}{l}\text { A spatial multi-criteria } \\
\text { analysis shell (MCAS-S) } \\
\text { using AHP }\end{array}$} & \multirow{2}{*}{$\begin{array}{l}\text { The analysis of time series data } \\
\text { - The linkage of time series and } \\
\text { signal processing methods to } \\
\text { spatial analysis } \\
\text { - Resolving scale }\end{array}$} & \multirow[b]{2}{*}{$\begin{array}{l}\text { Managing uncertainty } \\
\text { especially in the linkage } \\
\text { of scientific and social } \\
\text { domains }\end{array}$} & \multirow{2}{*}{$\begin{array}{l}\text { - Spatial MCDM tools can help integrate factual } \\
\text { information with value judgements and policy } \\
\text { goals in transparent and flexible way } \\
\text { - There is still considerable scope for } \\
\text { improvement in spatial data handling } \\
\text { technologies and analytical methods }\end{array}$} \\
\hline 7b) Lesslie et al. 2008 & $\begin{array}{l}\text { The Australian } \\
\text { rangelands }\end{array}$ & $\begin{array}{l}\text { Potential productivity for } \\
\text { livestock grazing } \\
\text { Outputs: composite maps to } \\
\text { show high potential } \\
\text { productivity and high } \\
\text { resource sensitivity index } \\
\text { values }\end{array}$ & & & & & & \\
\hline $\begin{array}{l}\text { 8) Bryan and } \\
\text { Crossman } 2008\end{array}$ & $\begin{array}{l}\text { Murray river } \\
\text { corridor, South } \\
\text { Australia, } \\
12,170 \mathrm{~km}^{2} \\
6.45 \text { ha resolution } \\
\text { grid } \\
\end{array}$ & $\begin{array}{l}\text { Identifying geographic } \\
\text { priorities for protection } \\
\text { and/or revegetation of } \\
\text { remnants and cleared areas } \\
\text { along lower catchment }\end{array}$ & $\begin{array}{l}\text { Evaluation criteria comprising of spatial } \\
\text { distribution of salinity; vegetation } \\
\text { management; opportunity costs of } \\
\text { agriculture ; and soil wind erosion } \\
\text { potential areas }\end{array}$ & Not mentioned & $\begin{array}{l}\text { - Spatial MCDM written in } \\
\text { the general Algebraic } \\
\text { Modelling System } \\
\text {-Linear programming }\end{array}$ & $\begin{array}{l}\text { Stakeholders could not justify } \\
\text { modifying the equal weights } \\
\text { applied to various objectives }\end{array}$ & $\begin{array}{l}\text { Decision maker's } \\
\text { judgements }\end{array}$ & $\begin{array}{l}\text { - Application of sensitivity analysis to decision } \\
\text { analysis } \\
\text { - The presented framework allows the influence } \\
\text { of different layers and objectives to be modified } \\
\text { according to stakeholders' priorities }\end{array}$ \\
\hline 9) Chen et al., 2010 & $\begin{array}{l}\text { Macintyre Brook } \\
\text { catchment, } \\
\text { Queensland } \\
4200 \mathrm{~km}^{2}\end{array}$ & $\begin{array}{l}\text { Identifying the potential } \\
\text { of expanding irrigated } \\
\text { cropping land-use }\end{array}$ & $\begin{array}{l}5 \text { criteria including conductivity of soil, } \\
\text { percent slope, soil texture, depth to } \\
\text { water-table, electrical conductivity of } \\
\text { groundwater }\end{array}$ & Not mentioned & Spatial AHP model & $\begin{array}{l}\text { The most critical shortcoming of } \\
\text { SA } \\
\text { is the lack of insight they provide } \\
\text { into the spatial aspects of weight } \\
\text { sensitivity }\end{array}$ & $\begin{array}{l}\text { Uncertainty in criteria } \\
\text { weights }\end{array}$ & $\begin{array}{l}\text { Developing a spatial, GIS-based AHP sensitivity } \\
\text { analysis tool }\end{array}$ \\
\hline $\begin{array}{l}\text { 10) Ananda and } \\
\text { Herath, } 2003\end{array}$ & $\begin{array}{l}\text { The Northeast } \\
\text { Victoria } \\
23,000 \mathrm{~km}^{2}\end{array}$ & $\begin{array}{l}\text { Comparing and ranking of } \\
\text { economic goals, } \\
\text { environmental goals, social } \\
\text { goals for regional forestry } \\
\text { strategies }\end{array}$ & $\begin{array}{l}20 \text { criteria including environmental, } \\
\text { economic and social criteria }\end{array}$ & 5 stakeholders & AHP & $\begin{array}{l}\text { - Adequacy of the preference } \\
\text { scale } \\
\text { - Constructing the decision } \\
\text { schema and weighting }\end{array}$ & $\begin{array}{l}\text { Uncertainty on weighting } \\
\text { criteria }\end{array}$ & $\begin{array}{l}\text { - The success of the method heavily depends on } \\
\text { the decision problem structuring } \\
\text { - The usefulness of AHP depends on the ability of } \\
\text { respondents to provide credible answers to the } \\
\text { questions posed } \\
\text {-Sensitivity analysis can show how the alternative } \\
\text { will be prioritised relative to other alternatives } \\
\text { with respect to each objective }\end{array}$ \\
\hline $\begin{array}{l}\text { 11) Qureshi and } \\
\text { Harrison, } 2003\end{array}$ & $\begin{array}{l}\text { Scheu Creek }(13 \\
\mathrm{km}) \text { in the } \\
\text { Johnstone } \\
\text { Catchment, } \\
\text { Queensland }\end{array}$ & $\begin{array}{l}\text { Comparing } 4 \text { riparian } \\
\text { revegetation options for } \\
\text { small-scale forestry } \\
\text { operations }\end{array}$ & $\begin{array}{l}6 \text { environmental, } 3 \text { social and } 3 \\
\text { economic sub-objectives } \\
\text { A questionnaire comprising of } 96 \\
\text { questions }\end{array}$ & $\begin{array}{l}5 \text { stakeholder } \\
\text { groups }\end{array}$ & $\begin{array}{l}\text { - AHP } \\
\text { - Weighted summation } \\
\text { - Expected Value } \\
\text { - Evamix }\end{array}$ & $\begin{array}{l}\text { - How to identify appropriate } \\
\text { stakeholder groups and their } \\
\text { representatives } \\
\text { - Unrealistic expectations about } \\
\text { policy decisions can be generated }\end{array}$ & $\begin{array}{l}\text { Problems with } \\
\text { inconsistencies in } \\
\text { preferences between } \\
\text { objectives }\end{array}$ & $\begin{array}{l}\text { Economic assessment can become a second tier } \\
\text { of the AHP prioritisation process to allow } \\
\text { scenario building of different management } \\
\text { options }\end{array}$ \\
\hline $\begin{array}{l}\text { 12) Ananda and } \\
\text { Herath, } 2008\end{array}$ & $\begin{array}{l}\text { The Northeast } \\
\text { Victoria } \\
23,000 \mathrm{~km}^{2}\end{array}$ & $\begin{array}{l}\text { Ranking alternative forest } \\
\text { management options }\end{array}$ & $\begin{array}{l}\text { Decision model in } 4 \text { level: } \\
\text { Forest management and planning as the } \\
\text { main objective in level } 1 \\
\text { Level } 2 \text { consists of } 5 \text { stakeholder groups } \\
\text { Level } 3 \text { consists of decision objectives } \\
\text { Level } 4 \text { : alternative forest management } \\
\text { options }\end{array}$ & $\begin{array}{l}5 \text { stakeholder } \\
\text { groups }\end{array}$ & AHP & $\begin{array}{l}\text { Structuring the decision problem } \\
\text { Obtaining the pairwise } \\
\text { comparisons }\end{array}$ & $\begin{array}{l}\text { Uncertainty on weighting } \\
\text { criteria }\end{array}$ & $\begin{array}{l}\text { Reducing the time required to conduct the } \\
\text { pairwise comparison } \\
\text { - Designing innovative and user friendly } \\
\text { questioning protocols } \\
\text { - improving cooperation between the respondent } \\
\text { and the analyst } \\
\text { Preferences are sensitive to the problem } \\
\text { structuring } \\
\text { Sensitivity analysis can be performed for both } \\
\text { stakeholder weights and attribute weights }\end{array}$ \\
\hline
\end{tabular}

To cite this article: Razieh Mosadeghi, Jan Warnken, Rodger Tomlinson \& Hamid Mirfenderesk (2012): Uncertainty analysis in the application of multi-criteria decision-making methods in

Australian strategic environmental decisions, Journal of Environmental Planning and Management, DOI:10.1080/09640568.2012.717886 
Table 1. Continued

\begin{tabular}{|c|c|c|c|c|c|c|c|c|}
\hline $\begin{array}{l}\text { Case number and } \\
\text { reference }\end{array}$ & $\begin{array}{c}\begin{array}{c}\text { Location } \\
\text { and } \\
\text { spatial extent } \\
(\mathbf{k m 2})\end{array} \\
\end{array}$ & $\begin{array}{l}\text { General aim of MCDM } \\
\text { method, (decision to be } \\
\text { made) }\end{array}$ & $\begin{array}{l}\text { Pt I: definition and weighting of } \\
\text { decision criteria }\end{array}$ & $\begin{array}{l}\text { No. of } \\
\text { Participants } \\
\text { (input) }\end{array}$ & Pt II: evaluation algorithm & Confronted Problems & uncertainty & Suggestions for further research and findings \\
\hline $\begin{array}{l}\text { 13) Xevi and Khan, } \\
2005\end{array}$ & $\begin{array}{l}\text { Murrumbidgee } \\
\text { catchment, New } \\
\text { South Wales } \\
1,218.08 \mathrm{~km} 2\end{array}$ & $\begin{array}{l}\text { Comparing the management } \\
\text { options for agricultural } \\
\text { water allocation }\end{array}$ & $\begin{array}{l}\text { Three objective functions: maximizing } \\
\text { net returns } \\
\text { (NR), minimizing variable cost (VC) } \\
\text { and minimizing total } \\
\text { supplementary groundwater pumping } \\
\text { requirements (TP) to } \\
\text { meet crop demand from the irrigated } \\
\text { areas }\end{array}$ & Not mentioned & Goal Programming & $\begin{array}{l}\text { Difficulty of selecting the target } \\
\text { values and weights for the different } \\
\text { goals }\end{array}$ & $\begin{array}{l}\text { Uncertainty involved } \\
\text { with climate, } \\
\text { environmental policy and } \\
\text { markets }\end{array}$ & None specified \\
\hline 14) Hajkowicz, 2006 & $\begin{array}{l}\text { Great Barrier Reef } \\
\text { catchments, } \\
\text { Queensland } \\
423,070 \mathrm{~km} 2\end{array}$ & $\begin{array}{l}\text { Constructing a single multi- } \\
\text { attributed index to measure } \\
\text { citizens' welfare derived } \\
\text { from a region's water } \\
\text { services }\end{array}$ & $\begin{array}{l}\text { Average rank position assigned to the } \\
\text { importance of } 14 \text { water services }\end{array}$ & $\begin{array}{l}\text { A survey of } 901 \\
\text { visitors and } \\
\text { residents }\end{array}$ & $\begin{array}{l}\text { MAUT (multi-attribute utility } \\
\text { theory) }\end{array}$ & $\begin{array}{l}\text { Identifying appropriate question } \\
\text { about the measurement of people's } \\
\text { environmental welfare }\end{array}$ & Problem structuring & None specified \\
\hline 15) Kodikara, 2008 & $\begin{array}{l}\text { Greater Melbourne, } \\
\text { Victoria } \\
\text { around } 8,000 \mathrm{~km} 2\end{array}$ & $\begin{array}{l}\text { Evaluating alternative } \\
\text { operating rules in } \\
\text { determining the optimum } \\
\text { operating } \\
\text { rules to manage the existing } \\
\text { urban water supply systems } \\
\text { considering }\end{array}$ & $\begin{array}{l}4 \text { system operations to generate } \\
\text { alternative operating rules including: } \\
\text { demand restriction policy; pumping; } \\
\text { hydropower generation; minimum } \\
\text { passing flows }\end{array}$ & $\begin{array}{l}3 \text { stakeholder } \\
\text { groups }\end{array}$ & PROMETHEE & $\begin{array}{l}\text { - Inability to represent the PM } \\
\text {-Evaluation by a single value } \\
\text { technical aspects in the evaluation } \\
\text { procedures }\end{array}$ & $\begin{array}{l}\text { "Internal uncertainty" } \\
\text { related to the process of } \\
\text { problem structuring and } \\
\text { analysis, and } \\
\text { "external uncertainty" } \\
\text { regarding the nature of } \\
\text { the environment }\end{array}$ & $\begin{array}{l}\text { - The choice of a suitable MCDM method } \\
\text { should be carefully considered } \\
\text { - Sensitivity analysis and introducing stochastic } \\
\text { extensions to the available MCDA methods to } \\
\text { deal with uncertainty }\end{array}$ \\
\hline 16) Hyde et al., 2005 & $\begin{array}{l}\text { using three } \\
\text { previously } \\
\text { published case } \\
\text { studies }\end{array}$ & $\begin{array}{l}\text { Re-examined the effects of } \\
\text { changes in criteria } \\
\text { weightings by introducing } \\
\text { new uncertainty analysis } \\
\text { technique }\end{array}$ & Not explicitly addressed & Not mentioned & Various MCDM techniques & $\begin{array}{l}\text { Shortcomings of the sensitivity } \\
\text { analysis methods }\end{array}$ & $\begin{array}{l}\text { Developed a new } \\
\text { distance-based } \\
\text { uncertainty analysis }\end{array}$ & $\begin{array}{l}\text { The proposed uncertainty analysis method } \\
\text { presented in this paper, can be extended to } \\
\text { incorporate the uncertainty in the determination } \\
\text { of the performance values of the criteria and } \\
\text { therefore the robustness of the ranking can be } \\
\text { ascertained based upon the simultaneous } \\
\text { variation of all of the input parameters within } \\
\text { their feasible or expected ranges. }\end{array}$ \\
\hline
\end{tabular}

To cite this article: Razieh Mosadeghi, Jan Warnken, Rodger Tomlinson \& Hamid Mirfenderesk (2012): Uncertainty analysis in the application of multi-criteria decision-making methods in 


\section{Discussion}

The ENV-MCDM applications reviewed in this study demonstrate a growing interest within Australian government agencies to apply these techniques for different stages of strategic environmental decision processes and more narrow spatial scenarios. Considerations of uncertainties and how they could affect method selection or the decision itself have not been detailed or systematic, certainly not from the broader scope of the dimensions identified in section 2.1 of this paper. This is partially based on the simple fact that most of the detailed considerations of uncertainty in environmental decision-making were not available at the time that these studies were carried out. This review points to a second obstacle, i.e. the apparent lack of congruence in the terminology of uncertainties of concern for MCDM analysts and environmental DMs. To overcome this gap, the linkage between uncertainty terminology used in MCDM and environmental science are highlighted in figure 2.

Examining the Australian case studies shows for broad scale and complex problems like National Resource Management (NRM) plans and the corresponding funding allocations, MCDM processes were mostly employed to develop a structure to achieve consensus amongst stakeholders. At this early stage, uncertainty was not considered as an important issue and the priority was to apply simple methods to help the end users understand the many facets of the decision making process. In light of the deliberations detailed in section 2.1, this type of uncertainty was largely epistemic with very little knowledge at the level of input, context and to some extent model structure uncertainties.

Decisions by catchment managers often have a narrower focus, spatially as well as objectively. Their decisions are underpinned by factual knowledge and detailed, spatially referenced data. Much of this data can be stored in GIS and used to derive performance measures. Relevant MCDM applications in this paper (case $6,7 \mathrm{a}, 7 \mathrm{~b}$ and, 8) showed a growing trend in integrating advanced MCDM techniques with GIS by various research groups. This integration allows:

- GIS capabilities to be used more effectively by experts within a decision-making body; 
- greater transparency in the outputs of the MCDM approaches; and

- spatial uncertainties to be highlighted and/or incorporated via GIS input data.

In this case, the integration of GIS and MCDM provide opportunities for visually communicating differences in the spatial pattern of outputs by using iterations and different criteria weightings. In other words, the underlying GIS information was considered reliable at the geographical scales relevant for catchment management, which would have eliminated much of the concern about epistemic input uncertainty. The remaining concerns about uncertainties focused largely on contextual issues at both epistemic and stochastic dimensions, i.e. how decisions would be affected by unpredictable physical changes as well as interactions between decision criteria and their weights. In this category, concerns for the latter were mostly remediated by performing basic uncertainty analysis (e.g. sensitivity analysis) for most of the case studies.

Decisions about water resource management, including water allocations, are often made at a sub-catchment level. For these scenarios, epistemic uncertainties and particularly model uncertainties (views on the importance of different 'services' requiring water allocations) are closely entwined with stochastic uncertainties (largely related to randomness in rainfall and flows). The most noteworthy work in this context was Hyde et al. (2005) who went beyond readily available sensitivity analyses to develop a new distanced-based uncertainty analysis approach to address issues with criteria weights estimation for situations with ambiguity over ascendancies in the source of uncertainty, i.e. the relevant effects of epistemic versus stochastic uncertainties. This further indicates that MCDM techniques alone will have difficulties in solving decision issues confronted with considerable stochastic uncertainties.

This review demonstrates that $50 \%$ of the 16 Australian case studies pointed out the key uncertainties with which they had to deal (cases 4, 7a, 7b, 10, 12, and 15). Four studies suggested a practical methodology to address these uncertainties (cases 10, 12, 15, 16). Apart from Hyde et al. (2005, see above), sensitivity analyses (SAs) were employed to illustrate how one alternative was prioritised in relation to other alternatives, with respect to each objective. 
Sensitivity analyses are not a common practice in the field of spatial MCDM. One of the most critical shortcomings of SA procedures is the lack of insight that they provide into the spatial aspects of weight sensitivity (case 9). To overcome this issue, Chen et al. (2010) presented a new approach for investigating the spatial dimension of multi-criteria weight sensitivity. Their approach was based on a generic SA methodology in a GIS-based AHP model to examine the sensitivity of MCDM evaluations to criteria weight changes and to subsequently visualize the spatial change dynamics (case 9). Others (Qi and Altinakar, 2011) developed GIS applications that incorporate Monte Carlo simulations to provide a decision support tool for a fairly narrowly defined problem. For future studies these approaches can be seen as an initial step towards adding a spatial dimension to the uncertainty analysis.

This case study analysis also reveals that stochastic uncertainty has not been addressed with the same rigour as epistemic uncertainty in strategic environmental decisions in Australia. This is particularly concerning when dealing with large scale problems (e.g. water resource allocation) where predicting natural and social behaviour involve higher levels of stochastic uncertainties. To address this kind of uncertainty, more attention should be directed towards visualizing the effects of uncertainty (i.e. using GIS) by using different scenarios for the future behaviour of natural, social and, economic systems.

In terms of epistemic uncertainty, this study recognized a gap relating to DMs preference uncertainties in method selection and structuring the evaluation criteria. These uncertainties are subject to the DMs knowledge of existing decision-making techniques and their understanding of the problem being structured and must be addressed in future applications of MCDM in environmental decisions. Improving the DMs knowledge about method selection techniques, group decision-making and, appropriate aggregation methods to obtain the final criteria weights can ameliorate the above-mentioned dimensions of uncertainty (Ozernoy, 1992; Tecle and Duckstein,1992; Yoon and Hwang, 1995; Poh, 1998; Sen and Yang, 1998; and Lu et al. 1999, Chen et al., 2011). 
A summary of ways to address uncertainty at each stage of the MCDM procedure is provided in Table 2, which also suggests directions for future MCDM applications. This summary highlights some of the most recent work proposing a Monte-Carlo Game Theory (MCGT) approach for dealing with uncertainty in the performance of alternatives (Madani and Lund, 2011). The most significant advantage of this approach is its ability to solve the problem even in the absence of cardinal information. In other words, this methodology, by using ordinal information, will make results more robust to performance uncertainties (Madani and Lund, 2011).

The suggested methods in Table 2 emphasize the need to consider uncertainty throughout the decision-making procedure. Currently most conventional uncertainty analyses are added at the end of the decision-making to demonstrate the effects of criteria weights changes, which is only one aspect of uncertainty. Instead, uncertainty should be considered throughout the process starting from problem structuring, identification of evaluation criteria and selecting the appropriate methodology.

Table 2. Recommended methods to deal with uncertainty in future application of MCDM.

\begin{tabular}{|c|c|c|}
\hline Source of uncertainty & Type of uncertainty & Methods to handle uncertainty \\
\hline Method selection & $\begin{array}{l}\text { DMs Preferences } \\
\text { Affected by context uncertainty }\end{array}$ & $\begin{array}{l}\text { - Tree diagrams (MacCrimmon, 1973; Yoon and } \\
\text { Hwang, 1995; Sen and Yang, 1998), } \\
\text { - Criteria approaches (Tecle and Duckstein, 1992), } \\
\text { - Expert/intelligent systems (Ozernoy, 1992; Poh, } \\
\text { 1998; Lu et al., 1999) }\end{array}$ \\
\hline Identification of criteria & $\begin{array}{l}\text { DMs Preferences } \\
\text { Affected by context uncertainty }\end{array}$ & $\begin{array}{l}\text { - Increase the public and policy makers' } \\
\text { awareness in regard to environmental issues } \\
\text { - Group decision making panels to identify the } \\
\text { evaluation criteria (Ananda and Herath, 2003) }\end{array}$ \\
\hline Criteria weights & DMs preferences and knowledge & $\begin{array}{l}\text { - Participation of multi-disciplinary experts } \\
\text { - Group decision making to weight the criteria } \\
\text { (Lahdelma and Salminen, 2001; Ananda and } \\
\text { Herath, 2003; Ananda and Herath, 2008) } \\
\text { - Select appropriate aggregation approach (Duke } \\
\text { and Aull-Hyde, 2002; Ananda and Herath, 2008) }\end{array}$ \\
\hline $\begin{array}{l}\text { Criteria estimation \& } \\
\text { alternative's selection }\end{array}$ & Model uncertainty & $\begin{array}{l}\text { - Using MCDM techniques incorporated with } \\
\text { decision theories which support handling } \\
\text { uncertainty (i.e. ELECTRE, PROMETHEE, } \\
\text { MAUT, Fuzzy sets theory, Random sets theory, } \\
\text { and Game theory) (Chen, 2005; Lahdelma et al., } \\
\text { 2006; Zhang and Achari, 2010; } \\
\text { Janssen et al., 2010; Zhang and Achari, 2010; } \\
\text { Chen et al., 2011) }\end{array}$ \\
\hline
\end{tabular}

To cite this article: Razieh Mosadeghi, Jan Warnken, Rodger Tomlinson \& Hamid Mirfenderesk (2012): Uncertainty analysis in the application of multi-criteria decision-making methods in Australian strategic environmental decisions, Journal of Environmental Planning and Management, DOI:10.1080/09640568.2012.717886 


\section{Conclusion}

This study confirms that MCDM techniques can assist stakeholders and decision-makers in unravelling some of the uncertainties inherent in environmental decision-making, borne out of the complexities of natural systems, a lack of sufficient data, a wide range of stakeholders and their associated objectives. This study combines the dimensions of uncertainty considered in environmental decision making processes and MCDM techniques. The Australian case studies analysed for this paper provided further evidence that appropriate MCDM techniques can be successfully employed in situations where epistemic uncertainties have a propensity to outweigh stochastic uncertainties. Depending on the scope and stage of the decision-making process, subsequent conventional sensitivity analyses can further resolve issues surrounding epistemic uncertainties, i.e. the effects of changes in criteria weights on the final results.

The proposed typology in this paper (section 2 and Figure 2) however, highlights that in practice, a particular type or level of uncertainty rarely manifests itself in isolation. In the first instance, MCDM experts should consider other aspects of epistemic uncertainty to be addressed within the framework of MCDM. Examples include uncertainties in problem structuring, identification of evaluation criteria and selecting the appropriate methodology. The recommended methods suggested in Table 2 provide some further directions for future studies in this area.

Environmental decision making processes are affected to a large degree by stochastic uncertainty, notably in the contextual and data input dimensions, and consequently are difficult to address with MCDM techniques alone. This becomes more complicated where predominantly epistemic uncertainties are affected by stochastic uncertainty, e.g. stakeholders may place unwarranted importance on random extreme weather events in response to global climate change simply because of their concerns about the 
impacts and unpredictability for small areas. Overall, any increases in extreme weather may still be of much lower impact than ongoing changes to land-use where much of the decision's controversy is founded on epistemic uncertainty, i.e. insufficient system knowledge about how certain changes will affect environmental and socio-economic outcomes. One possible approach to gain an understanding of the effects of some dimensions of stochastic uncertainty, e.g. data input and model uncertainties, relates to combining MCDM with other decision making tools such as GIS and simulation algorithms (e.g. Monte Carlo Simulation). This approach presents promising ways to examine the effects of uncertainty in a spatial context, i.e. the extent of the natural features and events. These would also assist in increasing the transparency of the decision-making process, a key issue for many stakeholders.

\section{Acknowledgment}

This research was performed as part of a $\mathrm{PhD}$ research at Griffith Centre for Coastal Management and funded by the Gold Coast City Council. We would like to acknowledge three anonymous reviewers for their constructive criticism that improved the final version of this work.

\section{References}

Ananda, J. and Herath G., 2003. The use of Analytic Hierarchy Process to incorporate stakeholder preferences into regional forest planning. Forest policy and economics, 5 (1), 13-26.

Ananda, J. and Herath G., 2008. Multi-attribute preference modelling and regional land-use planning. Ecological economics, 65 (2), 325-335.

Ananda, J. and Herath G., 2009. A critical review of multi-criteria decision making methods with special reference to forest management and planning. Ecological economics, 68 (10), 2535-2548.

Ascough, J.C., Maier, H.R., Ravalico, J.K. and Strudly, M.W., 2008. Future research challenges for incorporation of uncertainty in enviornmental and ecological decision-making. Ecological modelling, 219 (3-4), 383-399. 
Bowyer, J. K. and Veitch S. M., 1994. ASSESS: a system for selecting suitable sites for a land use. In: Proceeding of OZRI 8, 1994, Hobart, Australia.

Braaten, R., Dowling, T., Walker, J., and Veitch, S., 2001. A framework for using indicators and environmental software systems for analysis of catchment condition. In: Proceedings of the Fourth International Symposium, 22-25 May 2001, Banff, Canada. Environmental software systems, 4, 13-27.

Bryan, B. A. and Crossman N. D., 2008. Systematic regional planning for multiple objective natural resource management. Journal of environmental management, 88 (4), 1175-1189.

Bryan, B.A., Grandgirard, A., and Ward, J.R., 2009. Managing natural capital and ecosystemservices: Identifying strategic regional priorities in the South Australian Murray-Darling Basin. CSIRO Water for a Healthy Country National Research Flagship. Available from: http://www.clw.csiro.au/publications/waterforahealthycountry/2009/wfhc-managing-naturalcapital-mdb.pdf [Accessed 9 February 2011].

Chang, C.H., Yang, J.C., and Tung, Y.K., 1993. Sensitivity and uncertainty analysis of a sediment transport models: a global approach. Stochastic Hydrological Hydraulics, 7 (4), 299-314.

Chen, X.H., 2005. A research based on Fuzzy AHP for Multi-criteria supplier selection in supply chain. Thesis (Master degree). Taiwan National University of Science and Technology.

Chen, H., Wood, M.D, Linstead, C., and Maltby, E., 2011. Uncertainty analysis in a GIS-based multicriteria analysis tool for river catchment management. Environmental modelling \& software, 26 (4), 395-405.

Dessai, S. and Hulme M., 2007. Assessing the robustness of adaptation decisions to climate change uncertainties: A case study on water resources management in the East of England. Global environmental change, 17(1), 59-72. 
Dodgson, J.S., Spackman, M., Pearman, A. and Phillips, L. D., 2009. Multi-criteria analysis: a manual. Department for Communities and Local Government: London, UK. Available from: http://eprints.lse.ac.uk/12761/1/Multi-criteria_Analysis.pdf [Accessed 7 March 2011].

Dorini, G., Kapelan, Z. and Azapagic, A., 2011. Managing uncertainty in multiple-criteria decision making related to sustainability assessment. Clean technology and environmental policy, 13 (1), 133-139.

Dunn, W.N., 2001. Using the Method of Context Validation to Mitigate Type III Errors in Environmental Policy Analysis. In: M. Hisschemoller, R. Hoppe, W.N. Dunn, and J. Ravetz eds. Knowledge, Power and Participation in Environmental Policy. New Brunswick and London: Transaction Publishers, 417-436.

Figueira, J., Greco, S. and Ehrgott, M., 2005. Multiple Criteria Decision Analysis: State Of The Art Surveys. New York: Springer.

Funtowicz, S.O. and Ravetz, J., 1990. Uncertainty and Quality in Science for Policy. Dordrecht: Kluwer Academic Publishers.

Hajkowicz, S., 2002. Regional priority setting in Queensland: A multi-criteria evaluation framework. CSIRO Land and Water. Available from: http://live.greeningaustralia.org.au/nativevegetation/pages/pdf/Authors\%20H/3_Hajkowicz.pdf [Accessed 10 October 2010].

Hajkowicz, S. and Collins K., 2007. A review of multiple criteria analysis for water resourcce planning and management. Water resource management, 21(9), 1553-1566.

Hajkowicz, S. and McDonald G., 2006. The assets, threats and solvability(ATS) model for setting environmental priorities. Environmental policy \& planning, 8(1), 87-102.

Hajkowicz, S., Young, M., Wheeler, S., MacDonald, D.H., and Young, D., 2000 (a). Supporting decisions: understanding natural resource management assessment techniques. Adelaide: CSIRO Land and Water. Available from: 
http://www.clw.csiro.au/publications/consultancy/2000/support_decisions.pdf [Accessed 20 September 2009].

Hajkowicz, S.A., 2008. Supporting multi-stakeholder environmental decisions. Journal of environmental management, 88 (4), 607-614.

Hajkowicz, S. A. and Higgins A., 2008. A comparison of multiple criteria analysis techniques for water resource management. European journal of operational research, 184 (1), 255-265.

Hajkowicz, S.A., McDonald, G.T., and Smith, P.N., 2000 (b). An evaluation of multiple objective decision support weighting techniques in natural resource management. Environmental planning and management, 43(4) 505-518.

Harremoës, P., and Madsen, H., 1999. Fiction and reality in the modelling world balance between simplicity and complexity, calibration and identifiability, verification and falsification. Water Science and Technology, 39 (9), 1-8.

Herath, G., Prato T., 2006. Using Multi-criteria decision analysis in natural resource management, Burlington: Ashgate publisher.

Hill, M.J., Braaten, R., Veitch, S.M., Lees, B.G., and Sharma, S.,2005. Multi-criteria decision analysis in spatial decision support: the ASSESS analytic hierarchy process and the role of quantitative methods and spatially explicit analysis. Environmental modelling \& software, 20 (7), 955-976.

Hwang, C. L. and Yoon K., 1998. Multiple Attribute Decision Making - Methods and Application: A State-of-the-Art Survey. New york: Springer.

Hyde, K.M., Maier, H.R., and Colby, C.B., 2005. A distance-based uncertainty analysis approach to multi-criteria decision analysis for water resource decision making. Journal of environmental management, 77(4), 278-290.

IPCC, 2007. Climate Change 2007: Impacts, Adaptation and Vulnerability. M.L. Parry, O.F. Canziani, J.P. Palutikof, P.J. van der Linden and C.E. Hanson, eds. Cambridge University Press, Cambridge, UK. 
Itami, R.M. and MacLaren, G., 2001. Integrating the AHP with Geographic Information System for Assessing Resource Conditions in Rural Catchments in Australia, In: D. L. Schmoldt, J. kangas, G.A.Mendoza, and M. Pesonen, eds. The Analytic Hierarchy Process in Natural Resource and Environmental Decision Making. Netherlands: Kluwer Academic Publisher, 269-287.

Jankowski, P.,1995. Integrating geographical information systems and multiple criteria deicsion-making methods. International journal of geographical information systems, 9(3), 251-273.

Janssen, R., 1992. Multiple objective decision support for environmental management. London: Kluwer Academic publisher.

Janssen, J.A.E.B, Krol, M.S., Schielen, R.M.J., and Hoekstra, A.Y., 2010. The effect of modelling expert knowledge and uncertainty on multicriteria decision making: a river management case study. Environmental science \& policy, 13 (3), 229-238

Kiker, G.A., Bridges, T.S., Varghes, A., Seager, T.P., and Linkov, I., 2005. Application of Multicriteria decision analysis in environmental decision making. Integrated environmental assessment and management, 1(2), 95-108.

Klauer, B., and Brown, J.D., 2004. Conceptualising imperfect knowledge in public decision making: ignorance, uncertainty, error, and 'risk situations'. Environmental research, engineering and management, 27 (1), 124-128.

Kodikara, P. N., 2008. Multi-objective optimal operation of urban water supply systems. Thesis (PhD). Victoria University.

Koksalan, M., Wallenius, J., and Zionts, S., 2011. Multiple Criteria Decision Making: From Early History to the 21st Century. World Scientific Publishing Company.

Lahdelma R. and Salminen P., 2001. SMAA-2: Stochastic multicriteria acceptability analysis for group decision making. Operations research, 49(3), 444-54.

Lahdelma, R., Makkonen, S., and Salminen, P., 2006. Two ways to handle dependent uncertainties in multi-criteria decision problems. Omega, 37 (1), 79-92. 
Lai, E., Lundie, S., and Ashbolt, N.J., 2008. Review of multi-criteria decision aid for integrated sustainability assessment of urban water systems. Urban water, 5(4), 315-327.

Lee, G. and Chan, E., 2008. The Analytic Hierarchy Process (AHP) Approach for Assessment of Urban Renewal Proposals. Social indicators research, 89(1), 155-168.

Lesslie, R.G., Hill, M.J., Hill, P., Cresswell, H.P., and Dawson, S., 2008. The Application of a Simple Spatial Multi-Criteria Analysis Shell to Natural Resource Management Decision Making. In: C. Pettit, W. Cartwright, I. Bishopet, eds., Berlin Landscape Analysis and Visualisation:Spatial Models for Natural Resource Management and Planning. Springer, 73-96.

Li, Y., 2007. An intelligent, knowledge-based multiple criteria decision making advisor for systems design. Thesis (PhD). Georgia Institute of Technology.

Madani K. and Lund J.R., 2011. A Monte-Carlo game theoretic approach for Multi-Criteria Decision Making under uncertainty. Advances in water resources, 34 (5), 607-616.

Mendoza, G.A. and Martins H., 2006. Multi-criteria decision analysis in natural resource management: A critical review of methods and new modeling paradigms. Forest ecology and management, 230 $(1-3), 1-22$.

Molchanov, I.S., 2005. Theory of Random Sets. Berlin: Springer-Verlag.

Morgan, M.G. and Henrion, M., 1990. Uncertainty: A Guide to Dealing With Uncertainty in Quantitative Risk and Policy Analysis. Cambridge: Cambridge University Press.

Mosadeghi, R., Tomlinson R., Mirfenderesk, H., and Warnken, J., 2009. Coastal Management Issues in Queensland and Application of the Multi-Criteria Decision Making Techniques. Journal of coastal research, SI56, 1252-1256.

Murphy, P., Layton, R., Bevans, K., 2001. Criterium Decision Plus Users Guide, the Complete Decision Formulation, Analysis and Presentation for Windows, Version 3.0. Copyright 1995-2001. Info Harvest Inc. www.InfoHarvest.com. 
Nijkamp, P., Rietveld, P., and Voogd, H., 1990. Multicriteria evaluation in physical planning. North Holland: Amsterdam publisher,.

Norton, J.P., Brown, J.D., Mysiak, J., 2006. To what extent, and how, might uncertainty be defined? Comments engendered by "Defining uncertainty: a conceptual basis for uncertainty management in model-based decision support": Walker et al., Integrated Assessment 4:1, 2003. Integrated assessment, 6 (1), 83-88.

Oreskes, N.K., Shrader-Frechette, K., and Belitz, K., 1994. Verification, validation, and confirmation of numerical models in the earth sciences. Science, 263 (5147), 641-646.

Pérez, J., Jimeno, J.L., and Mokotoff, E., 2006. Another potential shortcoming of AHP. TOP, 14(1), 99111.

Qi, H.H. and Altinakar, M.S., 2011. A GIS-based decision support system for integrated flood management under uncertainty with two dimensional numerical simulations. Environmental modelling and software, 26(6), 817-821.

Refsgaard, J.C., van der Sluijs, J.P., Lajer Højberg, A., and Vanrolleghem, P.A., 2007. Uncertainty in the environmental modelling process A framework and guidance. Environmental modelling \& software, $22(11), 1543-1556$.

Royes, G. F. and Cid Bastos R., 2006. Uncertainty analysis in political forecasting. Decision support systems, 42(1), 25-35.

Saaty, T. L., 1980. The Analytic Hierarchy Process. New York: McGraw-Hill.

Schluter, M. and Ruger, N., 2007. Application of a GIS-based simulation tool to illustrate implications of uncertainties for water management in the Amudarya river delta. Environmental modelling \& software, $22(2), 158-166$.

Sen, P. and Yang, J., 1998. Multiple Criteria Decision support in Engineering Design. London: Springverlag. 
Seo, F. and Sakawa M., 1988. Multiple criteria decision analysis in regional planning: concepts, methods and applications. Dordrecht: Reidel.

Sheppard, S.R.J. and Meitner M., 2005. Using multi-criteria analysis and visualisation for sustainable forest management planning with stakeholder groups. Forest ecology and management, 207(1-2), 171-187.

Steuer, R.E., Gardiner, L. R., and Gray. J, 1996. A Bibliographic Survey of the Activities and International Nature of Multiple Criteria Decision Making. Journal of multi-criteria decision analysis, 5 (3), 195-217.

Tecle, A. and Duckstein L., 1992. A procedure for selecting MCDM techniques for forest resource management. In: Proceeding of the ninth international conference on Theory and Applications in Business, Industry, and Government, Springer-Verlag, 19-32.

Teegavarapu, R.S.V., 2010. Modeling climate change uncertainties in water resources management models. Environmental modelling \& software, 25(10), 1261-1265.

Triantaphyllou, E., 2000. Multi-Criteria Decision Making Methods: A Comparative Study. Dordrecht: Kluwer Academic Publishers.

Van der Sluijs, J.P., Janssen, P.H.M., Petersen, A.C., Kloprogge, P., Risbey, J.S., Tuinstra, W., Ravetz, J.R., 2004. RIVM/MNP Guidance for Uncertainty Assessment and Communication Tool Catalogue for Uncertainty Assessment. Utrecht University. Available from: www.nusap.net/downloads/detailedguidance.pdf [Accessed 10 June 2010].

VonWinterfeldt, D. and Edwards W., 1986. Decision Analysis and Behavioral Research. Cambridge: Cambridge University Press.

Walker, J. and Veitch S.M., 2000. Catchment condition in Australia: an assessment at the National scale. In: INDEX2000, Second Workshop on Environmental Indicators and Indicies. 16-19 July 2000 Neurtingen: Germany. 
Walker, W.E., Harremoe“s, P., Rotmans, J., Van der Sluijs, J.P., Van Asselt, M.B.A., Janssen, P., Krayer, V., and Krauss, M.P., 2003. Defining uncertainty a conceptual basis for uncertainty management in model-based decision support. Integrated assessment, 4 (1), 5-17.

Warmink, J.J., Janssen, J.A.E.B., Booij, M.J., and Krol, M.S., 2010. Identification and classification of uncertainties in the application of environmental models. Environmental modelling \& software, $25(2), 1518-1527$.

Webster, M., Forest, C., Reilly, J., Babiker, M., Kicklighter, D., Mayer, M., Prinn, R., Sarofim, M., Sokolov, A., Stone, P., and Wang, C., 2003. Uncertainty Analysis of Climate Change and Policy Response. Climatic change, 61(3), 295-320.

Xevi, E. and Khan S., 2005. A multi-objective optimisation approach to water management. Journal of environmental management, 77(4), 269-277.

Yoon, K.P. and Hwang, C. L., 1995. Multiple attribute decision making. California: Sage Publication. Zardari, N.H. and Cordery I., 2007. The use of a multicriteria method in irrigation water allocation. Agricultural journal, 2 (2), 236-241.

Zarghami M, Szidarovszky F. and Ardakanian R., 2008. A fuzzy-stochastic OWA model for robust multi-criteria decision making. Fuzzy optimization and decision making, 7, 1-15.

Zhang, K. and Achari, G., 2010. Uncertainty propagation in environmental decision-making, using random sets. Procedia environmental sciences, 2, 576-584.

Zopounidis, C. and Doumpos, M., 2002. Multi-criteria decision aid in financial decision making: methodologies and literature review. Journal of multi-criteria decision analysis. 11 (4-5), $167-$ 186. 